\title{
REVITALIZATION LIMING AND THE RESPONSE OF SOIL FAUNA
}

\author{
E. Kula
}

\author{
Received: February 23, 2010
}

\begin{abstract}
KULA, E.: Revitalization liming and the response of soil fauna. Acta univ. agric. et silvic. Mendel. Brun., 2010, LVIII, No. 4, pp. 149-158

In an area with the differentiated extend of revitalization liming (1986-2002), soil fauna (Elateridae, Staphylinidae, Diplura, Protura) determined through the method of tullgrens (2005) was confronted with the actual soil chemistry ( $\mathrm{pH}$, soil exchange sorption, the degree of the sorption complex saturation by basic cations, $\mathrm{C} / \mathrm{N}$ ratio, available nutrients $\mathrm{P}, \mathrm{Mg}, \mathrm{K}$ and $\mathrm{Ca}$ ).

Athous subfuscus (O. F. Müller) and Dalopius marginatus (L.) accepted the broad extent of soil pH (2.86.15). The abundance of Elateridae and Protura was affected by soil chemistry and the content of nutrient elements while Staphylinidae and Diplura were without any response. Canonical analysis shows the complexity of applied factors whereas the environment showed a limited impact on the abundance of monitored fauna.
\end{abstract}

liming, pH, nutrient elements, C/N ratio, Elateridae, Athous subfuscus, Staphylinidae, Protura, Diplura, soil fauna

Through the long-term air-pollution impact in forest ecosystems of the Ore Mountains, soil environment has been disturbed and forest disintegration and changes in the species structure of forests reflecting in the established stands of substitute species occurred (Slodičák et al., 2009).

In acid forest soils, the abundance of macrofauna is very low (Kautz and Topp, 1998). In consequence of soil-chemical changes and the growth of herb vegetation new environment is created for soil fauna (Makeschin and Rodenkirchen, 1994; Kreutzer, 1995; Eisenbeis et al., 1997; Schäffer et al., 2001), which can be changed due to the fast effect of liming within one year (Hartmann et al., 1989; Irmler and Heydemann, 1989; Weber and Eisenbeis, 1992). However, it differs from medium- and long-term impacts of the application of dolomitic limestone (Meyer and Steinberg, 1994; Engel, 1995; Schauermann, 1987; Potthoff et al., 1999; Makeschin, 1994; Deleporte and Tillier, 1999). Site conditions changed due to air-pollution effects and soil and epigeal fauna modified by them, the area became for entomologists uninteresting. Thus, a survey is missing on its qualitative and quantitative development of soil fauna in the Ore Mountains area in the second half of the $20^{\text {th }}$ century.

The soil and epigeal fauna in mountain spruce forests is generally poor. With high probability it was affected by acidification. On the other hand, the high diversity of forest tree species and herb undergrowth in the air-polluted area of Sněžník (Kula and Machová, 2006) is the course of an extraordinary food offer for caterpillars which is reflected in the diversity of moths (Kula, 2007) and other phytophages.

An animal component participating in decomposition processes includes both acidophilous species and species requiring neutral and alkaline reaction (pH). In the 70s and the 80s of the last century, the extensive terrestrial and aerial liming of stands of the eastern Ore Mts. was realized (62 thousand ha) (Kubelka et al., 1995) with the aim to contribute to revitalization of the soil environment and thus indirectly also the soil and epigeal fauna. At the same time, established stands of substitute trees with the high proportion of broadleaves (birch, mountain ash, alder, aspen) also contributed to the improvement of soil conditions (Ulbrichová and Podrázský, 2002; Möllerová, 2004). 


\section{METHODS}

From the many stands of aerial-limed substitute species at the area of Forest District Klášterec nad Ohří (1986-2002), 49 stands were selected, which characterize a wide area according to time and frequency of the application repetition at altitudes 740-960 m. Both unlimed sites and localities with one to four applications of dolomitic limestone (at a rate of 2.5-3 t.ha ${ }^{-1}$ ) were noted generally at an interval of 5-6 years in the period 1986-2002. Concentration on stands in forest type groups $6 \mathrm{~K}, 7 \mathrm{~K}$ and marginally $6 \mathrm{~S}$ contributed to the homogenization of conditions. Based on general characteristics, (6K) Acidic Spruce-Beech forest (Piceeto-Fagetum acidophilum) and (6S) Fresh, nutrient-medium SpruceBeech forest (Piceeto-Fagetum mesotrophicum) are typical sites for locations at altitudes 650-950 m with natural species composition Fagus sylvatica L., Abies alba Mill. and Picea abies (L.) Karst. Mean annual temperature reaches $4.5-5.5^{\circ} \mathrm{C}$, annual precipitation 900-1050 mm, growing season amounts to 115130 days. 7K - Acidic Beech-Spruce forest (FagetoPiceetum acidophilum) is the typical site of upland locations of the Ore Mts. (altitude 900-1050m) with a mean annual temperature $4-4.5^{\circ} \mathrm{C}$ and annual precipitation 1050-1200 mm, growing season 100 115 days and natural species composition P. abies, F. sylvatica and A. alba (Průša, 2001). Always four soil samples $(25 \times 25 \times 15 \mathrm{~cm})$ were taken in each stand in the spring (May/June) and late summer (September) aspect $2005(\Sigma 392)$. In the course of field sampling, samples were stored in a snow cache at a temperature of $4{ }^{\circ} \mathrm{C}$ before transport to the laboratory. The temperature extraction in tullgrens took place for a period of three weeks and soil fauna concentrated in an intercepting tray (basin) with $0.5 \%$ formaldehyde was subsequently preserved in $75 \%$ ethanol. Half of samples from the spring aspect was stored in a cooling box with $5^{\circ} \mathrm{C}$ for 21 days, samples from the late summer aspect were stored in a karst cave with $5^{\circ} \mathrm{C}$ (Kula, Menšík, 2010). The mean abundance of soil fauna (pcs.m-2) was determined summarily from spring and late summer samplings being evaluated in relation to the number of applications of dolomitic limestone, soil/site preparation and soil chemistry (Tab. I). With respect to the numerical representation and the extraordinary demandingness of determination the species spectrum was specified only in Lumbricidae (Kula and Menšík, 2010) and Elateridae (larvae), which were determined by S. Laibner from Choceň. Other components of soil fauna were dealt with from the point of view of quantity. Soil characteristics of monitored stands include exchangeable $\mathrm{pH} / \mathrm{KCl}$, total carbon and nitrogen, soil exchangeable sorption $(\mathrm{T})$ and the degree of saturation of an adsorption complex by basic cations (V) and available nutrients $\mathrm{P}, \mathrm{Mg}$, $\mathrm{K}$ and $\mathrm{Ca}$ (Menšík and Kula, 2010). The abundance of selected groups of species of invertebrates and partial parameters of soils of a humus horizon were subject to a canonical analysis (Meloun et al., 2005;
StatSoft ČR s. r. o., 2007). Before the analysis, data were standardized and particular variables showed normal distribution with parameters $(0,1)$.

\section{RESULTS AND DISCUSSION}

The monitored area with forest stands in Forest District Klášterec nad Ohří was affected by the longterm process of acidification as well as by revitalization liming, which took place with various intensity in 1986-2002. Regardless of other partial characteristics, we evaluated seven animal groups with direct food and developmental relationships to the soil environment. Effects of liming depend on site factors, the type of a preparation used, liming dose/rate, grain size and the method of application, to task the impact of liming is evaluated as a dynamic factor (Persson, 1988), thus assessing its effects is related to a period how long after application the monitoring is carried out.

\section{Elateridae}

The coenosis of Elateridae shows specific position because adults can occur as secondary pests on assimilatory organs. Larvae (wireworms) are an important component of forest soils where the larvae participate in decomposition (Nielsen, 1974, 1975, Schauermann, 1986). Elateridae rank among species with a 3-year length of development (larvae 2 years) Dalopius marginatus (L.) or up to 6-year development Athous subfuscus (O. F. Müller), Selatosomus aeneus (L.). Thus, the cumulated reserve of larvae is created in the soil environment (Miller, 1956; Strey, 1972; Schwenke, 1974). The most important species is A. subfuscus, which feeds on humus, animals or their residues (Strey, 1972), various plant parts (Schaerffenberg, 1942, Kř́istek, 1979), leaves of beech (Moritz, 1986), seeds (Escherich, 1923, Blunck and Mühlmann, 1954) and various types of litterfall (Moritz, 1986). Imagoes do damage to bark of shoots or buds and larvae are harmful to the root system of plants. In mixed pine forests, larvae show relatively small abundance (38ind. ${ }^{-2}$ ), of which A. subfuscus 16.2 ind. $\mathrm{m}^{-2}$ and D. marginatus 12.6 ind. $\mathrm{m}^{-2}$. In spruce stands, D. marginatus and A. subfuscus are dominant (Schwenke, 1974). Iller (1956) determined the abundance of 40-50 larvae (wireworms) per $\mathrm{m}^{2}$ as a critical limit for the origin of damage on field crops. In stands of substitute species, such an abundance was not found.

Wireworms of 17 species of Elateridae were caught in the monitored area of the Klášterec Forest District in stands limed differentially and soil/site treated before reforestation. The abundance of wireworms was defined by 12-72ind. ${ }^{-2}$. The highest abundance of wireworms was noted at localities, which were not limed or were limed only once but without site preparation $\left(66-72\right.$ ind. $\left.\mathrm{m}^{-2}\right)$. On the other hand, decreased abundance 12-40 ind. $\mathrm{m}^{-2}$ occurred in stands, which were repeatedly limed and at sites disturbed by various technologies (Tab. I). A. subfuscus $(53.75 \%)$ and D. marginatus $(20.16 \%)$ ranked among 


\begin{tabular}{|c|c|c|c|c|c|c|c|c|c|c|c|c|c|c|c|c|c|c|c|c|}
\hline 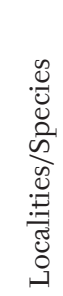 & 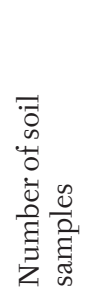 & 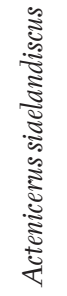 & 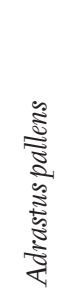 & 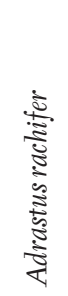 & 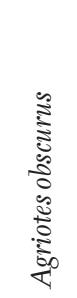 & 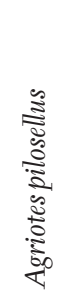 & 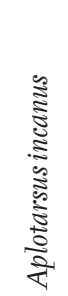 & 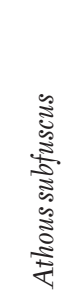 & 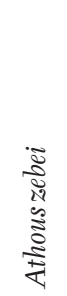 & 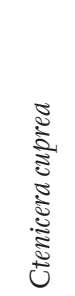 & 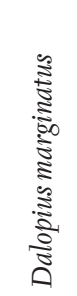 & 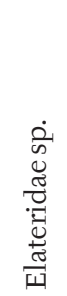 & 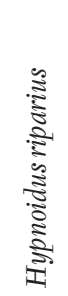 & 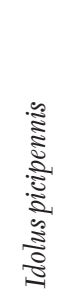 & 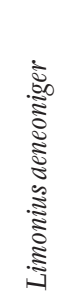 & 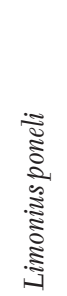 & 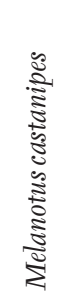 & 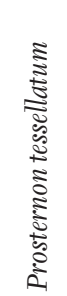 & 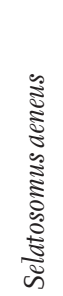 & $\underset{\tilde{I}}{\stackrel{\pi}{ \pm}}$ \\
\hline A & 32 & 0.00 & 0.00 & 0.00 & 0.50 & 0.00 & 0.00 & 45.50 & 1.00 & 0.50 & 10.50 & 7.00 & 3.00 & 1.00 & 2.00 & 0.50 & 0.00 & 0.00 & 1.00 & 72.50 \\
\hline B & 8 & 0.00 & 0.00 & 0.00 & 0.00 & 2.00 & 0.00 & 4.00 & 2.00 & 0.00 & 4.00 & 0.00 & 8.00 & 0.00 & 0.00 & 0.00 & 0.00 & 0.00 & 2.00 & 22.00 \\
\hline C & 96 & 0.00 & 1.00 & 0.00 & 2.50 & 0.00 & 0.17 & 25.00 & 1.00 & 2.00 & 13.17 & 3.67 & 3.50 & 0.00 & 0.00 & 0.00 & 0.17 & 0.00 & 0.67 & 52.83 \\
\hline D & 88 & 0.00 & 0.55 & 0.00 & 1.09 & 0.18 & 0.18 & 18.55 & 0.18 & 1.27 & 11.64 & 1.64 & 2.73 & 0.00 & 0.00 & 0.18 & 0.36 & 0.18 & 0.91 & 39.64 \\
\hline $\mathbf{H}$ & 48 & 0.33 & 0.00 & 0.33 & 0.00 & 0.00 & 0.00 & 17.67 & 0.33 & 1.00 & 5.00 & 1.67 & 2.33 & 0.33 & 0.33 & 0.00 & 0.00 & 0.00 & 0.00 & 29.33 \\
\hline CH & 8 & 0.00 & 0.00 & 0.00 & 30.00 & 0.00 & 0.00 & 22.00 & 0.00 & 2.00 & 12.00 & 0.00 & 0.00 & 0.00 & 0.00 & 0.00 & 0.00 & 0.00 & 0.00 & 66.00 \\
\hline I & 8 & 0.00 & 0.00 & 0.00 & 0.00 & 0.00 & 0.00 & 8.00 & 0.00 & 0.00 & 2.00 & 2.00 & 0.00 & 0.00 & 0.00 & 0.00 & 0.00 & 0.00 & 0.00 & 12.00 \\
\hline $\begin{array}{l}\text { A } \\
B \\
C \\
D \\
E \\
F \\
G \\
H \\
C H\end{array}$ & $\begin{array}{l}\text { With } \\
\text { Once } \\
\text { Once } \\
\text { Once } \\
2-3 \text { ti } \\
2-3 \text { ti } \\
2-3 \text { ti } \\
\text { With } \\
2-3 \text { ti }\end{array}$ & $\begin{array}{l}\text { lime } \\
\text { lime } \\
\text { mes } \\
\text { mes } \\
\text { mes } \\
\text { out li }\end{array}$ & $\begin{array}{l}\text { with } \\
\text { with } \\
\text { with } \\
\text { med } \\
\text { imed } \\
\text { med } \\
\text { ning }\end{array}$ & $\begin{array}{l}\text { out si } \\
\text { the " } \\
\text { the "l } \\
\text { witho } \\
\text { with } \\
\text { with } \\
\text { on agr }\end{array}$ & $\begin{array}{l}\text { te pre } \\
\text { excava } \\
\text { pulldo } \\
\text { ut site } \\
\text { he "ex } \\
\text { he "bu } \\
\text { icultu }\end{array}$ & $\begin{array}{l}\text { parati } \\
\text { tor" p } \\
\text { zer" } \\
\text { prep } \\
\text { cavat } \\
\text { lldoz } \\
\text { ral lat }\end{array}$ & $\begin{array}{l}\text { n } \\
\text { epar } \\
\text { epar } \\
\text { atiol } \\
\text { " pr } \\
\text { " pr } \\
\text { (fie } \\
\text { (fie }\end{array}$ & $\begin{array}{l}\text { ation o } \\
\text { ation o } \\
\text { eparati } \\
\text { eparati } \\
\text { ld. mea }\end{array}$ & ion o & $\begin{array}{l}\text { site } \\
\text { site }\end{array}$ & & & & & & & & & & \\
\hline
\end{tabular}

generally distributed eudominant species. Hypnoidus riparius (Fabr.) (6.43\%) reached a dominant position (Tab. II). From the analysis of abundance of particular species of Elateridae in relation to the forest type group significant dependences did not become evident through differentiated site conditions. The soil environment chemistry of H horizon where the development of larvae is concentrated appears to be the decisive criterion of long influence of liming and soil preparation. The soil $\mathrm{pH}$ at monitored localities with the occurrence of larvae was defined by 2.84-6.15, which was accepted by A. subfuscus at a balanced proportion. D. marginatus was profiled by higher abundance at $\mathrm{pH}<3.5$. The high range of soil $\mathrm{pH}(2.96-5.53)$ was determined at Ctenicera cuprea (Fabr.). Although the abundance of larvae of Elateridae was slightly decreased with the decreasing acidity it is not possible to consider soil pH to be an important differentiation criterion (Tab. II). The species diversity was partly negatively affected by receding acidity (Tab. II). Detailed information on the effect of $\mathrm{pH}$ on the development of Elateridae has not been mentioned in literature but it is not possible to exclude that soil conditions can be one of causes of the different species spectrum of Elateridae in field, meadow and forest ecosystems. Differences were determined at some species of Elateridae due to the soil exchangeable sorption (Agriotes obscurus (L.). Generally, very low abundance occurred at the high degree of the sorption complex saturation by basic cations. The decrease of abundance wireworms occurred at the optimum C/N ratio (Tab. II). According to the content of nutrient elements in a humus horizon, the higher abundance of wireworms occurs at the surplus of phosphorus, deficit of magnesium, surplus of calcium and optimum of potassium (Tab. III). In spite of facts mentioned above, it is not possible to accept unambiguous conclusions because limed areas show generally the increased content of nutrients and a comparative site with an insufficient supply is missing. If larvae of Elateridae can be hardly classified from the point of view of a trophic level (Axelsson et al., 1984, Persson et al., 1980), results of Wolters (1989) class unambiguously wireworms A. subfuscus to humiphagous specie their unspecific feeding behaviour being widely independent on soil conditions, which is in accordance with other authors.

\section{Staphylinidae}

Data on the occurrence of Staphylinidae in air-polluted areas and limed stands are missing. The occurrence of larvae and adults determined by the method of photoeclectors is a more objective procedure than soil samples because more stable and less fluctuating part of the Staphylinidae coenosis is noted including often even more rare and less numerous species. Nevertheless, experience 
II: The abundance of species of Elateridae in the humus layer depending on its properties (Forest District Klášterec)

\begin{tabular}{|c|c|c|c|c|c|c|c|c|c|c|c|c|}
\hline \multirow{3}{*}{ Species } & \multicolumn{12}{|c|}{ Abundance $\left(\mathrm{ks.m}^{-2}\right)$} \\
\hline & \multicolumn{4}{|c|}{ pH } & \multicolumn{2}{|c|}{$\mathbf{T}$} & \multicolumn{4}{|c|}{$\mathbf{V}$} & \multicolumn{2}{|c|}{$\mathbf{C}: \mathbf{N}$} \\
\hline & $<3.5$ & $3.5-4.5$ & $>4.5$ & pH & $125-250$ & $>250$ & $0-30$ & $30-50$ & $50-80$ & $80-100$ & $0-15$ & $15-25$ \\
\hline Actenicerus siaelandiscus & 0.08 & 0.00 & 0.00 & 3.46 & 0.00 & 0.04 & 0.06 & 0.00 & 0.00 & 0.00 & 0.00 & 0.05 \\
\hline Adrastus pallens & 0.08 & 0.40 & 1.25 & $3.04-4.76$ & 0.00 & 0.39 & 0.23 & 0.00 & 2.00 & 0.00 & 1.11 & 0.20 \\
\hline Adrastus rachifer & 0.15 & 0.00 & 0.00 & $3.14-3.46$ & 0.00 & 0.09 & 0.11 & 0.00 & 0.00 & 0.00 & 0.00 & 0.10 \\
\hline Agriotes obscurus & 1.54 & 2.40 & 0.00 & $2.84-4.05$ & 10.00 & 1.00 & 2.17 & 0.00 & 0.00 & 0.00 & 3.56 & 1.10 \\
\hline Agriotes pilosellus & 0.00 & 0.13 & 0.25 & $3.52-5.53$ & 0.00 & 0.09 & 0.06 & 0.00 & 0.00 & 1.00 & 0.00 & 0.10 \\
\hline Aplotarsus incanus & 0.23 & 0.27 & 0.00 & $3.01-3.84$ & 0.00 & 0.22 & 0.23 & 0.29 & 0.00 & 0.00 & 0.00 & 0.25 \\
\hline Athous subfuscus & 22.69 & 22.27 & 22.50 & $2.84-6.15$ & 19.33 & 22.74 & 23.83 & 15.71 & 29.60 & 6.00 & 25.33 & 21.90 \\
\hline Athous zebei & 0.69 & 0.27 & 0.25 & $2.96-5.53$ & 0.00 & 0.52 & 0.57 & 0.29 & 0.00 & 1.00 & 0.67 & 0.45 \\
\hline Ctenicera cuprea & 1.31 & 2.13 & 1.00 & $2.91-5.63$ & 1.33 & 1.52 & 1.66 & 0.86 & 2.00 & 0.00 & 1.56 & 1.50 \\
\hline Dalopius marginatus & 11.15 & 4.67 & 6.75 & $2.84-6.15$ & 5.33 & 8.65 & 10.00 & 2.00 & 8.80 & 3.00 & 10.89 & 7.90 \\
\hline Elateridae sp. & 2.23 & 2.53 & 3.75 & x & 1.33 & 2.65 & 2.40 & 2.57 & 4.40 & 1.00 & 3.78 & 2.30 \\
\hline Hypnoidus riparius & 2.77 & 3.07 & 1.75 & $2.96-5.53$ & 4.00 & 2.61 & 2.63 & 4.57 & 0.00 & 4.00 & 1.56 & 2.95 \\
\hline Idolus picipennis & 0.00 & 0.40 & 0.00 & $4.04-4.48$ & 0.00 & 0.13 & 0.00 & 0.86 & 0.00 & 0.00 & 0.44 & 0.05 \\
\hline Limonius aeneoniger & 0.15 & 0.40 & 0.00 & $2.96-4.48$ & 0.00 & 0.22 & 0.23 & 0.29 & 0.00 & 0.00 & 0.44 & 0.15 \\
\hline Limonius poneli & 0.31 & 0.00 & 0.00 & $2.91-3.32$ & 0.00 & 0.17 & 0.23 & 0.00 & 0.00 & 0.00 & 0.22 & 0.15 \\
\hline Melanotus castanipes & 0.15 & 0.13 & 0.00 & $3.05-4.41$ & 0.00 & 0.13 & 0.11 & 0.00 & 0.40 & 0.00 & 0.00 & 0.15 \\
\hline Prosternon tessellatum & 0.08 & 0.13 & 0.00 & $3.16-4.03$ & 0.00 & 0.09 & 0.11 & 0.00 & 0.00 & 0.00 & 0.00 & 0.10 \\
\hline Selatosomus aeneus & 0.85 & 0.53 & 0.25 & $2.91-5.53$ & 0.00 & 0.70 & 0.86 & 0.00 & 0.00 & 1.00 & 0.44 & 0.70 \\
\hline Abundance & 44.46 & 39.73 & 37.75 & & 41.33 & 41.96 & 45.49 & 27.43 & 47.20 & 17.00 & 50.00 & 40.10 \\
\hline N - individuals & 578 & 298 & 151 & & 62 & 965 & 796 & 96 & 118 & 17 & 225 & 802 \\
\hline N - soil samples & 208 & 120 & 64 & & 24 & 368 & 280 & 56 & 40 & 16 & 72 & 320 \\
\hline
\end{tabular}

T- the sorption capacity of soil

$\mathrm{V}$ - the sorption complex saturation by bases

III: The abundance of species of Elateridae in the humus layer depending on the content of nutrient elements (P. Mg. Ca. K) (Forest District Klášterec)

\begin{tabular}{|c|c|c|c|c|c|c|c|c|c|c|}
\hline \multirow{3}{*}{$\begin{array}{c}\text { Nutrients } \\
\text { Species }\end{array}$} & \multicolumn{10}{|c|}{ Abundance (ks.m-2) } \\
\hline & \multicolumn{3}{|c|}{$\mathbf{P}$} & \multicolumn{3}{|c|}{ Mg } & \multicolumn{2}{|c|}{$\mathrm{Ca}$} & \multicolumn{2}{|c|}{$\mathbf{K}$} \\
\hline & $<10$ & $10-30$ & $>30$ & $<150$ & $150-400$ & $>400$ & $150-500$ & $>500$ & $<200$ & $200-400$ \\
\hline Actenicerus siaelandiscus & 0.05 & 0.00 & 0.00 & 0.13 & 0.00 & 0.00 & 0.08 & 0.00 & 0.05 & 0.00 \\
\hline Adrastus pallens & 0.19 & 0.00 & 3.33 & 0.13 & 0.00 & 1.23 & 0.08 & 0.70 & 0.18 & 2.00 \\
\hline Adrastus rachifer & 0.09 & 0.00 & 0.00 & 0.13 & 0.10 & 0.00 & 0.15 & 0.00 & 0.09 & 0.00 \\
\hline Agriotes obscurus & 0.79 & 4.00 & 10.00 & 4.53 & 0.29 & 0.15 & 2.38 & 0.61 & 1.45 & 2.40 \\
\hline Agriotes pilosellus & 0.09 & 0.00 & 0.00 & 0.00 & 0.10 & 0.15 & 0.00 & 0.17 & 0.09 & 0.00 \\
\hline Aplotarsus incanus & 0.23 & 0.00 & 0.00 & 0.13 & 0.10 & 0.46 & 0.08 & 0.35 & 0.18 & 0.40 \\
\hline Athous subfuscus & 22.56 & 14.00 & 30.67 & 21.07 & 23.24 & 23.08 & 20.77 & 24.52 & 21.68 & 30.00 \\
\hline Athous zebei & 0.56 & 0.00 & 0.00 & 0.53 & 0.67 & 0.15 & 0.62 & 0.35 & 0.45 & 0.80 \\
\hline Ctenicera cuprea & 1.67 & 0.00 & 0.67 & 0.93 & 1.81 & 1.69 & 1.31 & 1.74 & 1.68 & 0.00 \\
\hline Dalopius marginatus & 8.19 & 10.00 & 10.67 & 14.67 & 6.38 & 4.62 & 7.38 & 9.65 & 8.14 & 11.20 \\
\hline Elateridae sp. & 2.28 & 4.00 & 5.33 & 1.87 & 2.86 & 2.92 & 1.54 & 3.74 & 2.27 & 5.20 \\
\hline Hypnoidus riparius & 2.93 & 0.67 & 1.33 & 2.13 & 2.76 & 3.23 & 1.77 & 3.74 & 2.86 & 1.20 \\
\hline Idolus picipennis & 0.14 & 0.00 & 0.00 & 0.00 & 0.10 & 0.31 & 0.00 & 0.26 & 0.14 & 0.00 \\
\hline Limonius aeneoniger & 0.23 & 0.00 & 0.00 & 0.27 & 0.29 & 0.00 & 0.15 & 0.26 & 0.23 & 0.00 \\
\hline Limonius poneli & 0.19 & 0.00 & 0.00 & 0.27 & 0.19 & 0.00 & 0.31 & 0.00 & 0.18 & 0.00 \\
\hline Melanotus castanipes & 0.14 & 0.00 & 0.00 & 0.00 & 0.29 & 0.00 & 0.15 & 0.09 & 0.14 & 0.00 \\
\hline Prosternon tessellatum & 0.09 & 0.00 & 0.00 & 0.00 & 0.10 & 0.15 & 0.08 & 0.09 & 0.09 & 0.00 \\
\hline Selatosomus aeneus & 0.74 & 0.00 & 0.00 & 0.27 & 1.05 & 0.46 & 0.62 & 0.70 & 0.73 & 0.00 \\
\hline Abundance & 41.16 & 32.67 & 62.00 & 47.07 & 40.29 & 38.62 & 37.46 & 46.96 & 40.64 & 53.20 \\
\hline N - individuals & 885 & 49 & 93 & 353 & 423 & 251 & 487 & 540 & 894 & 133 \\
\hline $\mathbf{N}$ - probes & 344 & 24 & 24 & 120 & 168 & 104 & 208 & 184 & 352 & 40 \\
\hline
\end{tabular}


IV: The mean abundance of soil fauna (ind. $\mathrm{m}^{-2}$ ) at localities according to the number of applications of dolomitic limestone and site preparation not differentiating FTG (Forest District Klášterec)

\begin{tabular}{|c|c|c|c|c|c|c|c|c|c|}
\hline 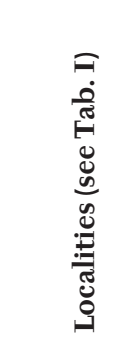 & 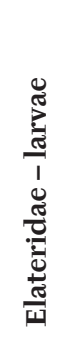 & 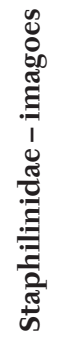 & 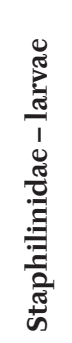 & 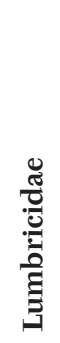 & 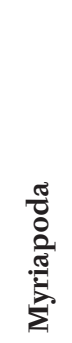 & 芳 & $\begin{array}{l}\frac{\pi}{0} \\
\text { है } \\
\stackrel{0}{0}\end{array}$ & 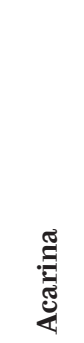 & $\frac{\pi}{\mathscr{B}}$ \\
\hline \multicolumn{10}{|c|}{ Abundance (pcs.m-2) } \\
\hline $\mathbf{A}$ & 174 & 50 & 106 & 75 & 242 & 834 & 1641 & 3753 & 24 \\
\hline B & 68 & 34 & 80 & 34 & 740 & 20 & 676 & 3336 & 38 \\
\hline C & 146 & 57 & 127 & 72 & 351 & 461 & 2352 & 4313 & 99 \\
\hline D & 124 & 74 & 112 & 73 & 235 & 256 & 1606 & 3674 & 70 \\
\hline $\mathbf{E}$ & 81 & 77 & 95 & 60 & 184 & 41 & 2580 & 3042 & 31 \\
\hline $\mathbf{F}$ & 121 & 72 & 124 & 61 & 357 & 301 & 1493 & 2559 & 46 \\
\hline G & 82 & 44 & 85 & 66 & 240 & 685 & 933 & 2207 & 20 \\
\hline $\mathbf{H}$ & 64 & 61 & 126 & 91 & 243 & 104 & 1142 & 2420 & 16 \\
\hline CH & 78 & 62 & 140 & 46 & 898 & 22 & 3072 & 5512 & 158 \\
\hline I & 28 & 70 & 122 & 78 & 194 & 50 & 1502 & 2392 & 0 \\
\hline
\end{tabular}

V: The abundance of soil fauna in the humus layer depending on its properties (Forest District Klášterec)

\begin{tabular}{|c|c|c|c|c|c|c|c|c|c|}
\hline \multirow{3}{*}{ Species } & \multicolumn{9}{|c|}{ Abundance (ind.m-2) } \\
\hline & \multicolumn{3}{|c|}{ pH } & \multicolumn{4}{|c|}{$\mathbf{V}$} & \multicolumn{2}{|c|}{ C:N } \\
\hline & $<3.5$ & $3.5-4.5$ & $>4.5$ & $0-30$ & $30-50$ & $50-80$ & $80-100$ & $0-15$ & $15-25$ \\
\hline Staphylinidae imagoes & 67 & 58 & 59 & 67 & 48 & 54 & 52 & 44 & 67 \\
\hline Staphylinidae larvae & 113 & 110 & 96 & 115 & 87 & 97 & 101 & 76 & 115 \\
\hline Myriapoda & 271 & 284 & 246 & 267 & 286 & 207 & 467 & 159 & 291 \\
\hline Protura & 413 & 400 & 153 & 393 & 493 & 230 & 35 & 285 & 386 \\
\hline Diplura & 51 & 60 & 29 & 54 & 40 & 49 & 19 & 37 & 53 \\
\hline Collembola & 1611 & 1684 & 1326 & 1682 & 1164 & 1504 & 1089 & 1711 & 1569 \\
\hline Acarina & 3499 & 3034 & 3035 & 3505 & 2433 & 3101 & 2864 & 3729 & 3215 \\
\hline
\end{tabular}

$\mathrm{V}$ - the sorption complex saturation by bases

from a limed area of the Buttersteig site (Forest District Litvínov) showed that even determination at the level of a species did not specify an actual bioindication species, which would be affected by liming and responded to the change of a population density (Kula, 2009).

The abundance of larvae determined by tullgrens was twice higher than that of imagoes independently of site conditions, namely 4-77 and 80$140 \mathrm{ind} \cdot \mathrm{m}^{-2}$, respectively. Based on the evaluation of the total occurrence of Staphylinidae partial shift is noticeable towards sites where repeated liming was carried out (except an unlimed stand established on agricultural land) (Tab. IV). With respect to a fact that chemistry characterizing a humus layer did not become evident even in one indicator as significant for abundance it was possible to state that Staphylinidae were not affected by liming (Tab. V, VI).

\section{Protura}

Protura are typical inhabitants of forest humus. According to Franz (1959), they are sensitive to the application of dolomitic limestone, which was also proved by Fritsche (1994) by the determined increase of their abundance from high to the lowest application rate.

In the monitored area, a significant difference became evident in abundance (20-834ind. $\left.\mathrm{m}^{-2}\right)$. Maximum values occurred in the control stand with forest soil but, at the same time, high population densities were also related to a repeatedly limed stand. Nevertheless, there is a discrepancy of very low population density (20-50ind. $\mathrm{m}^{-2}$ ) at sites without application or only with the only application of dolomitic limestone (Tab. IV). There are interesting differences in abundance between forest type groups (FTG) 6K (493 ind. $\mathrm{m}^{-2}$ ) and 7K (70 ind. $\mathrm{m}^{-2}$ ). Protura rank among soil fauna responding most 
sensitively to soil properties. Decreased abundance was determined at $\mathrm{pH}>4.5$, at a heavily saturated soil sorption complex and low $\mathrm{C} / \mathrm{N}$ ratio in $\mathrm{H}$ horizon. Low population densities were noted at the optimum content of $\mathrm{P}, \mathrm{K}$ and surplus of $\mathrm{Mg}$ and $\mathrm{Ca}$ (Tabs. V, VI).

\section{Diplura}

Diplura are a saprophagous component of the fauna of forest litter and humus. Relevant data on impacts of acidification and liming are missing. The abundance of Diplura was relatively low, nevertheless, they were profiled by the frequency of liming. The higher proportion of Diplura occurred in unlimed soils and maximum abundance occurred on afforested agricultural land (Tab. IV). At Diplura, a relationship to soil chemistry was not identified although the lower abundance of Diplura was related to sites with $\mathrm{pH}>4.5$ and with heavily saturated soil sorption complex, low $\mathrm{C} / \mathrm{N}$ ratio and the insufficient content of $\mathrm{P}$ (Tabs. V, VI).

\section{Canonical analysis}

For canonical analysis (Meloun et al., 2005; StatSoft ČR s. r. o., 2007), two groups of data were selected. The first group consisted of the soil fauna of invertebrates including variable larvae of Elateridae, larvae of Staphylinidae, Lumbricidae, Myriapoda, Protura, Diplura, Collembola and Acarina (ind.m ${ }^{-2}$ ). Into the second group, variables were included corresponding to the soil profile $\mathrm{H}(\mathrm{pH} / \mathrm{KCl}$, saturation of the soil sorption complex by bases (V), C/N ratio and the content of $\mathrm{P}, \mathrm{Mg}, \mathrm{Ca}, \mathrm{K}$ and total sulphur $\left(\mathrm{S}_{\mathrm{t}}\right)$ ). Before the actual analysis, data were standardized and particular variables showed normal distribution with parameters $(0,1)$.

The estimated model was highly significant ( $p=0.00902)$ and the coefficient of determination (canonical correlation coefficient $\mathrm{R}^{2}=0.148$ ) corresponded to the high dependence closeness. A test of the significance of canonical roots showed that only the first root with a canonical correlation coefficient $\mathrm{R}=0.8454$ was statistically significant. The structure of factors (Tab. VII) indicates that a canonical variable "invertebrates" shows higher loading for original variables Myriapoda, Collembola, Acarina and Diplura. However, all these loadings are negative, which indicates that soil conditions in horizon $\mathrm{H}$ affect this soil animal component negatively. The rate of effect is not high because it corresponds to the relatively low value of variability (0.2337) and redundancy (0.1670). The canonical variable "soil" shows higher loading for original variables " $\mathrm{pH} / \mathrm{KCl}$, $\mathrm{C} / \mathrm{N}$ and $\mathrm{S}_{\mathrm{T}}$ ". All these loadings are positive. Thus, it is possible to conclude that higher $\mathrm{pH}$ (less acid environment), higher $\mathrm{C} / \mathrm{N}$ ratio (soil rich in carbon or poor in nitrogen) and also the increased amount of total sulphur create unfavourable conditions in soil (H horizon) for the development of a monitored animal component. Changes in the structure of fauna after liming will be gradual and will follow (with

VI: The abundance of the soil fauna in the humus layer depending on the content of nutrient elements (P. Mg. Ca. K) (Forest District Klásterec)

\begin{tabular}{|c|c|c|c|c|c|c|c|c|c|}
\hline \multirow{3}{*}{$\begin{array}{c}\text { Nutrients } \\
\text { Species } \\
\end{array}$} & \multicolumn{9}{|c|}{ Abundance (ind.m-2) } \\
\hline & \multicolumn{2}{|c|}{$\mathbf{P}$} & \multicolumn{3}{|c|}{ Mg } & \multicolumn{2}{|c|}{$\mathrm{Ca}$} & \multicolumn{2}{|c|}{$\mathbf{K}$} \\
\hline & $<10$ & $10-30$ & $<150$ & $150-400$ & $>400$ & $150-500$ & $>500$ & $<200$ & $200-400$ \\
\hline Staphylinidae imagoes & 63 & 67 & 70 & 55 & 70 & 69 & 58 & 63 & 64 \\
\hline Staphylinidae larvae & 110 & 106 & 119 & 110 & 97 & 113 & 106 & 110 & 102 \\
\hline Myriapoda & 278 & 199 & 286 & 289 & 224 & 283 & 261 & 276 & 218 \\
\hline Protura & 400 & 40 & 457 & 430 & 166 & 425 & 323 & 400 & 51 \\
\hline Diplura & 53 & 25 & 49 & 56 & 43 & 41 & 59 & 51 & 49 \\
\hline Collembola & 1574 & 1772 & 1703 & 1489 & 1636 & 1547 & 1628 & 1525 & 2291 \\
\hline Acarina & 3235 & 3895 & 3612 & 3262 & 2970 & 3332 & 3356 & 3189 & 4389 \\
\hline
\end{tabular}

VII: Structure of factors - variable soil fauna - invertebrates (variance of the first root 0.2337 ; redundancy 0.1670 ) and variables soil $-H$ horizon (variance of the first root 0.1991; redundancy 0.1423)

\begin{tabular}{lccc}
\hline \multicolumn{1}{c}{ Soil fauna } & lst root - insect & Soil (H) & lst root - soil (Ah) \\
\hline Elateridae larvae & 0.038802 & H_pH (KCl) & 0.648048 \\
Staphylinidae imagoes & 0.038802 & H_V & 0.235188 \\
Staphylinidae larvae & 0.311328 & H_C/N & 0.641965 \\
Lumbricidae & 0.311328 & H_P & 0.160566 \\
Myriapoda & -0.845907 & H_Mg & 0.388249 \\
Protura & 0.141043 & H_Ca & 0.094998 \\
Collembola & -0.751920 & H_K & 0.381304 \\
Acarina & -0.507551 & H_St & 0.611740 \\
Diplura & -0.600859 & & \\
\hline
\end{tabular}


a time delay) the process of changes in the chemistry of soils subject to acidification for nearly 50 years.

\section{CONCLUSION}

The chemical composition of the humus horizon $\mathrm{H}$ was evaluated (soil reaction, base-exchange complex, $\mathrm{C} / \mathrm{N}$ ratio, available nutrients) at $6 \mathrm{~K}$ and $7 \mathrm{~K}$ sites in stands limed in various extent and differentiated by the method of site treatment before reforestation. Elateridae show differences in abundance without an unambiguous relationship to the site/ soil preparation and the number of repeated liming. On the basis of soil characteristics, indications of a possible preference for acid site conditions occur (D. marginatus). A. subfuscus accepting the balanced wide range of $\mathrm{pH}$ values (2.8-6.15). Partial effects on the increased abundance of larvae became evident at the low degree of the sorption complex saturation by basic cations, increased content of $\mathrm{Ca}, \mathrm{P}$ and the lack of $\mathrm{Mg}$ in the humus horizon. Sta- phylinidae showed a partial shift towards repeatedly limed stands but a relationship to the soil environment chemistry was not defined.

Protura were significantly profiled by their decreased occurrence at $\mathrm{pH}>4.5$, at the saturated soil sorption complex, low $\mathrm{C} / \mathrm{N}$ ratio in $\mathrm{H}$ horizon, and the optimum $\mathrm{P}$ and $\mathrm{K}$ content and surplus of $\mathrm{Mg}$. At Diplura, a response to liming was not determined.

The canonical analysis showed that the evaluated parameters of the soil environment (H horizon) affected the monitored soil fauna of invertebrates. The rate of this effect at particular species is not generally high and, at the same time, it relates only to some parameters of the soil environment. The analysis proves considerable complexity of problems with the intent that it is necessary to suppose indispensable effects of climatic conditions and the mutual competition of species and other aspects of the environment natural resistance to the abundance of a monitored animal component.

\section{SOUHRN}

Revitalizační vápnění a reakce půdní fauny

V území s diferencovaným rozsahem revitalizačního vápnění (1986-2002) byla metodou tullgrenů (2005) zachycená půdní fauna (Elateridae, Staphylinidae, Diplura, Protura) konfrontována s aktuálním půdním chemismem (pH, půdní výměnná sorpce, stupeň nasycení sorpčního komplexu bazickými kationy, C/N, přístupné živiny $\mathrm{P}, \mathrm{Mg}, \mathrm{K}$ a Ca) (Tab. I-VI).

Z porostů náhradních dřevin letecky vápněných na území lesní správy Klášterec nad Ohří bylo v roce 2005 vybráno 49 porostů, které charakterizují široké revitalizační území dle doby a četnosti opakování aplikace v poloze 740-960 m n. m. Byla podchycena stanoviště nevápněná i lokality s jedinou až čtyřmi aplikacemi vápnitého dolomitu v dávce (2,5-3 t.ha $\left.{ }^{-1}\right)$ zpravidla v časovém odstupu 5-6 let z období 1986-2002. Vždy čtyři půdní sondy $(25 \times 25 \times 15 \mathrm{~cm})$ byly odebrány v porostu v jarním (V/ VI) a pozdně letním (IX) aspektu (2005) ( $\Sigma$ 392). Tepelná extrakce v tullgrenech probíhala po dobu tří týdnů.

Průměrná abundance půdní fauny $\left(\mathrm{ks} . \mathrm{m}^{-2}\right)$ byla stanovena sumárně z odběru v jarním a pozdně letním termínu a hodnocena ve vazbě na počet aplikací vápnitého dolomitu a přípravu půdy (Tab. I, IV) a půdní chemismus (Tab. II-III, V-VI). Vzhledem k početnímu zastoupení a mimořádné náročnosti determinace bylo druhové spektrum stanoveno pouze v čeledi Lumbricidae (Kula, Menšík; 2010) a Elateridae (larvy), které determinoval prom. biol. S. Laibner z Chocně. Ostatní složky půdní fauny byly řešeny na úrovni řádů z hlediska kvantity.

Abundance půdní fauny a dílčí parametry půd humusového horizontu byly po standardizaci dat podrobeny kanonické analýze (Tab. VII).

Abundance 17 druhů larev kovaříkovitých byla vymezena 12-72 ks.m-2, přičemž nejvyšší byla v lokalitách bez vápnění, případně jednou vápněných, ale bez přípravy stanoviště (66-72 ks.m²). Naproti tomu snížená abundance $12-40$ ks.m ${ }^{-2}$ byla v porostech opakovaně vápněných a různými technologiemi narušených stanovišt' (Tab. I).

Půdní pH $(2,84-6,15)$ na sledovaných lokalitách ve vyrovnaném zastoupení akceptoval Athous subfuscus (O. F. Müller), zatímco Dalopius marginatus (L.) se profiloval vyšší abundancí při pH $<3,5$. Široké rozpětí půdního $\mathrm{pH}(2,96-5,53)$ bylo stanoveno u druhu Ctenicera cuprea (Fabr.) (Tab. II). Abundance a druhová diverzita larev kovaříkovitých se mírně snižovala s klesající aciditou. Diference byly stanoveny u larev druhu Agriotes obscurus (L.) v důsledku půdní výměnné sorpce (Tab. II), obecně velmi nízká abundance byla při vysokém stupni nasycení sorpčního komplexu bazickými kationy a snížení abundance u drátovců nastalo při optimálním poměru C/N (Tab. II).

Z úrovně obsahu živinových prvků v humusovém horizontu se jeví vyšší abundance drátovců při nadbytku fosforu, nedostatku hořčíku, nadbytku vápníku, optimu draslíku (Tab. III).

Staphylinidae vykazovali dílčí posun k opakovaně vápněným porostům, ale vazba na chemismus půdního prostř̀edí nebyla definována (Tab. IV-VI). Protura se významně profilovala sníženým výsky- 
tem při $\mathrm{pH}>4.5$, při nasyceném půdním sorpčním komplexu, nízkém poměru $\mathrm{C} / \mathrm{N}$ v horizontu $\mathrm{H}$ a optimu P, K a nadbytku Mg (Tab. II-III). U Diplura nebyla stanovena reakce na vápnění.

Kanonická analýza ukázala, že hodnocené parametry půdního prostředí (horizont H) sledovanou půdní faunu bezobratlých ovlivňují. Míra tohoto působení u jednotlivých zástupců není obecně velká a současně se vztahuje jen na některé parametry půdního prostředí (Tab. VII). Statistická analýza vycházející z abundance živočišných skupin a podrobného vymezení půdních podmínek potvrdila značnou komplexnost problematiky. Pro detailnější analýzu faktorů stanovené výše abundance sledované živočišné složky nejsou dostupná odpovídající data charakterizující mikroklimatické podmínky, vzájemnou konkurenci druhů a další aspekty přirozeného odporu prostředí.

vápnění, pH, živinové prvky, C/N, Elateridae, Athous subfuscus, půdní fauna

This work was carried out under projects funded by the grant project NAZV QH 82113 and VZ MSM 6215648902, and on the financial support of regional join stock companies and concerns: Netex Ltd. and Alcan Děčín Extrusions Ltd. in Děčín, District Authorities in Děčín, ČEZ Co. Prague, Lafarge cement Co. in Čížkovice, Severočeské doly Co. Chomutov, Dieter Bussmann Ltd. in Ústí n. L.

\section{SUMMARY}

In an area with the differentiated extent of revitalization liming, soil fauna determined by the method of tullgrens was confronted with the actual soil chemistry. Selected sites were evaluated (49), viz. both unlimed and localities with the only to four applications of dolomitic limestone at a rate of 2.5-3 t.ha $\mathrm{h}^{-1}$, generally at a time delay of 5-6 years in the period 1986-2002. Soil samples $(25 \times 25 \times 15 \mathrm{~cm})$ were taken in a stand in the spring (May/June) and in the late summer (September) aspect 2005 ( $\Sigma$ 392). The temperature extraction in tullgrens took place for the period of three weeks.

The mean abundance of soil fauna (ind. $\mathrm{m}^{-2}$ ) was determined summarily from samplings carried out in summer and autumn terms and evaluated in relation to FTG, the number of applications of dolomitic limestone and site/soil preparation and soil chemistry. The soil fauna abundance and partial parameters of soils of the humus horizon were subject to canonical analysis after the standardization of data. On the basis of the analysis of abundance of particular species of Elateridae in relation to the FTG a significant dependence did not become evident within differentiated site conditions. Soil pH at monitored localities with the occurrence of larvae of Elateridae was defined by 2.84-6.15, which was accepted by Athous subfuscus (O. F. Müller) in balanced proportion while Dalopius marginatus (L.) was profiled by higher abundance at $\mathrm{pH}<3.5$. The broad range of soil $\mathrm{pH}(2.96-5.53)$ was determined at Ctenicera cuprea (Fabr.). Differences were determined at some species of wireworms of Elateridae due to the soil exchangeable sorption (Agriotes obscurus (L.)). On the basis of the nutrient element content in the humus horizon the higher abundance of wireworms occurs at the surplus of phosphorus, shortage of magnesium, surplus of calcium and optimum of potassium. The canonical analysis showed that evaluated parameters of the soil environment (H horizon) affected the monitored fauna of invertebrates. The rate of the effect at particular species is not generally high and, at the same time, it is related only to some parameters of the soil environment. The analysis proved considerable complexity of these problems, namely that it was necessary to suppose indispensable effects of climatic conditions and the mutual competition of species and other aspects of the natural resistance of the environment on the abundance of the monitored animal component.

\section{REFERENCES}

BLUNCK, H., MÜHLMANN, H., 1954: Elateridae. In: SORAUER, P. (ed.): Handbuch für Pflanzenkrankheiten 5. Berlin, Parey Verlag, 25-61.

DELEPORTE, S., TILLIER, P., 1999: Long-term effects of mineral amendments on soil fauna and humus in an acid beech forest floor. Forest Ecol. Manage., 118: 245-252. ISSN: 0378-1127.

EISENBEIS, G., FRITSCH, N., LENZ, R., WEBER, M., 1997: Bodenfauna und Waldkalkung. In: Waldschäden, Boden- und Wasserversauerung durch Luftschadstoffe in Rheinland-Pfalz. Ministerium für Umwelt und Forsten Rheinlandpfalz, Mainz, 4766. SUB Göttingen 206-337-205
ENGEL, M., 1995: Die Fliegen und Mücken (Diptera) eines sauren Fichtenforstes in der Eifel und ihre Reaktionen auf Kalkungsmassnahmen. PollichiaBuch, Nr. 32, Bad Duerkheim, 283 S.

ESCHERICH, K., 1923: Die Forstinsekten Mitteleuropas II. Berlin, Parey Verlag, 152-167.

FRANZ, H., 1959: Das biologishe Geschehen im Waldboden und seine Beeinflussung durch die Kalkdüngung. Allg. Forstztg. (Wien), 70: 178-181. ISSN 1286-4560.

FRITSCH, N., 1994: Auswirkungen der Waldkalkung auf die Bodenmesofauna. Dissertation, Johannes- Gutenberg-Universität Mainz, 207 S.

HARTMANN, P., FISCHER, R., SCHEIDLER, M., 1989: Auswirkungen der Kalkdüngung auf die Bo- 
denafauna in Fichtenforsten. Verh. Ges. Ökol., 17: 585-589. ISSN: 0940-7782.

IRMLER, U., HEYDEMANN, B., 1989: Der Einfluss einer Kalkmerggelbehandlung auf die Bodenfauna dreier schleswig-holsteinischer Waldtypen. Verh. Ges. Ökol., 17: 591-596. ISSN: 0940-7782.

KAUTZ, G., TOPP, W., 1998: Nachhaltige waldbauliche Massnahmen zur Verbesserung der Bodenqualität, Forstwiss. Cent. bl., 117: 23-43. ISSN: 00158003.

KREUTZER, K., 1995: Effects of forest liming on soil processes. Plant Soil, 168-169: 447-470. ISSN: 0032-079X

KRISTEK, J., 1979: Schnellkäfer (Coleoptera, Elateridae) der Fichtenbestände. Acta Univ. Agric. (Brno) C (Fac. silvicult.), 48: 53-76. ISSN: 1211-8516.

KUBELKA, L., KARÁSEK, A., RYBÁŘ, V., BADALÍK, V., SLODIČÁK, M., 1992: Obnova lesa v imisemi poškozené oblasti severovýchodního Krušnohoří. MZe ČR Praha, 133 s.

KULA, E., 2007: Motýli porostů náhradních dřevin v imisním území Sněžníku. Nakl. Lesnická práce, s.r.o., 107 s. ISBN: 978-80-86386-89-8.

KULA, E., 2009: Půdní a epigeická fauna stanovišt' ovlivnèných vápnèním a její dynamika. Hradec Králové: Grantová služba Lesy ČR, 06: 438 s. ISBN: 978-8086945-15-6.

KULA, E., MACHOVÁ, I., 2006: Floristická diverzita a fauna monofágů motýlů v imisním území (Sněžník, Děčínská vrchovina). In: SLODIČÁK, M., NOVÁK, J. (eds.): Lesnický výzkum v Krušných horách. Recenz. sb.z celostátní véd. konf., Teplice 20.04.06, VÚLHM VS Opočno, 233-248. ISBN: 80-86461-66-1.

KULA, E., MENŠÍK, L., 2010: Žížaly (Lumbricidae) imisní oblasti ovlivněné melioračním vápněním. J. For. Sci. (in print). ISSN: 1212-4834.

MAKESCHIN, F., 1994: Experimentelle Untersuchungen zur Besiedelung anthropogen devastierter, saurer Waldböden mit leistungsfähigen Lumbriciden. Akademischer Verlag, München, 197 S.

MAKESCHIN, F., RODENKIRCHEN, H., 1994: Saure Beregnung und Kalkung - Auswirkungen auf Bodenbiologie und Bodenvegetation. Allg. Forst Z., 14: 759-764. ISSN 1286-4560.

MELOUN, M., MILITKÝ, J., HILL, M., 2005: Počítačová analýza vícerozmérných dat. Academia Praha, 137-170.

MENŠÍK, L., KULA, E., 2010: Forest floor and soils of limed stands of substitute species of Forest District Klášterec nad Ohř́ in the Ore Mountains. J. For. Sci (in print). ISSN: 1212-4834.

MEYER, E., STEINBERGER, K. H., 1994: Über die Bodenfauna in Wäldern Vorarlberhs (Österreich) - Bestand und Auswirkungen von Gesteinsmehlapplikationen. Verh. Ges. Ökol., 23: 149-164. ISSN: 0940-7782.

MILLER, F., 1956: Zemédèlská entomologie. Nakl. ČSAV, 219.

MÖLLEROVÁ, J., 2004: Olše jako meliorační dřevina (přehled). In: Dřeviny a lesní puida - biologická meliorace a její využití - Sborník z konference. ČZU, 31-33.
MORITZ, G., 1986: Zur Ökologie von Shnellkäfern (Coleoptera: Elateridae) in Buchen- und Fichtenwäldern. Diplomarbeit, Göttingen.

NIELSEN, B. O., 1974: The phenology of beech canopy insects in Denmark. Vid. Meddr. Dansk Naturh. Foren., 137: 95-124. ISSN: 1502-0800.

NIELSEN, B. O., 1975: The species composition and community structure of the beech canopy fauna in Denmark. Vid. Meddr. Dansk Naturh. Foren., 138: 137-170. ISSN: 1502-0800.

PERSSON, T., 1988: Effects of acidification and liming on soil biology. In: ANDERSSON, F., PERSSON, T. (eds.): Liming as a Measure to Improve Soil and Tree Condition in Areas Affected By Air Pollution. Results and experiences of an ongoing research programme, National Swedish environmental protection Board Report 3518, Stockholm, Sweden, 53-70.

POTTHOFF, M., MUHS, A., BEESE, F., ASCHE, N., 1999: Regenwurmaktivität nach Anwendung von Hüttenkalk bzw. Brikettier-Braunkohleasche zur Schutzkalkung in Wäldern. Mitt. Dtsch. Bodenkdl. Ges., 91: 695-698. ISSN: 1817-3047.

PRŮŠA, E., 2001: Pěstování lesui na typologických základech. Lesnická práce s.r.o., 593 s. ISBN: 80-8638610-4.

SCHAERFFENBERG, B., 1942: Der Einfluss von Humusgehalt und Feuchtigkeit des Bodens auf die Frasstätigkeit der Elateridenlarven. Anz. Schädlingskd., 18: 133-136. ISSN 1436-5693.

SCHÄFFER, J., GEISSEN, V., HOCH, R., WILPERT, K., 2001: Waldkalkung belebt Böden wieder. Allgem. Forst-Z., 56: 178-181. 1106-1109. ISSN 1286-4560.

SCHAUERMANN, J., 1986: Die Tierwelt, ihre Nahrungsbeziehnungen und ihre Rolle. In: ELLENBERG, H., MAYER, R., SCHAUERMANN, J. (eds.): Ökosystemforschung, Ergebnisse des Solling-Projektes. Ulmer, Stuttgart, 179-266.

SCHAUERMANN, J., 1987: Tiergesellschaften der Wälder im Solling unter dem Einfluss von Luftschadstoffen und künstlichem Säure- und Düngereintrag. Verh. Ges. Ökol., 16: 53-62. ISSN: 09407782.

SCHWENKE, W., 1974: Die Forstschädlinge Europas. Verlag Paul Parey, Hamburg, 500 S.

SLODIČÁK M., BALCAR V., NOVÁK J., ŠRÁMEK V. ET AL., 2008: Lesnické hospodaření v Krušných horách. Edice Grantové služby LČR, 03: 478. ISBN: 978-80-86461-91-5.

STATSOFT ČR S. R.O. 2007: STATISTICA Cz (softwarový systém pro analýzu dat), verze 8.0. www. statsoft.cz.

STREY, G., 1972: Ökoenergetische Untersuchungen an Athous subfuscus Mïll. und Athous vittatus Fbr. (Elateridae, Coleoptera) in Buchenwäldern. Dissertation, Göttingen, $135 \mathrm{~S}$.

ULBRICHOVÁ, I., PODRÁZSKÝ, V., 2002: Hodnocení listnatých přípravných dřevin z hlediska obnovy a ochrany půdy v Krušných horách. In: SLODIČÁK, M., NOVÁK, J. (eds.): Výsledky lesnického 
výzkumu v Krušných horách v roce 2001, VÚLHM: 2128. ISSN 80-86461-20-3.

WEBER, M., EISENBEIS, G., 1992: Auswirkungen der Waldkalkung auf die Bodenmakrofauna. Ergebnisse aus einem Koefern Buchen Standort im Pfälzer Wald. Mitt. a.d. Forstl. Vers. Anst. Rheinland Pfalz, 21: 175-188.
WOLTERS, V., 1989: The influence of omnivorous elaterid larvae on the microbial carbon cycle in different forest soils. Oecologia, 80: 405-413. ISSN: 0029-8549.

\section{Address}

prof. Ing. Emanuel Kula, CSc., Ústav ochrany lesů a myslivosti, Mendelova univerzita v Brně, Zemědělská 3 , 61300 Brno, Česká republika, e-mail:kula@mendelu.cz 